\title{
Membrane Bioreactors Used for Treatment of Food Industry Effluents
}

\author{
AL-Saadi Anmar Joudah ${ }^{1, *}$, and Gabriel Racoviteanu ${ }^{2}$ \\ ${ }^{1}$ TUCEB, Dept. of Water Engineering, Bucharest, Sector 2, 124 Lacul Tei Bvd., www.utcb.ro, Romania \\ 2 TUCEB, Dept. of Water Engineering, Bucharest, Sector 2, 124 Lacul Tei Bvd., www.utcb.ro, Romania
}

\begin{abstract}
Effluents from the food industry determine pollution problems due to high COD and BOD concentrations. Compared to other industrial divisions, food industry requires large amounts of water. In this study, MBR was based on submerged hollow fibers membranes functioning by low vacuum. Two phases of bioreactor treatment were carried out with different HRTs (2-8) and (2-24) hours. Sixteen water samples collected from the influent and the effluent of the bioreactor during the two phases. $\mathrm{NaOCl}$ compound was added during the backwashing process for all tests, and the same compound was added with mixed liquid for the second test at period 24 hour of aeration. The samples were tested for twelve water quality tests: temperature, Dissolved Oxygen, pH, Turbidity, Total Suspended Solids, Mixed Liquor Suspended Solids, Chemical Oxygen Demand, Biochemical Oxygen Demand, Nitrate Nitrogen, Ammonium Nitrogen, Total Phosphate, and Ortho Phosphate. The results indicated that the bioreactor system can be used efficiently to treat industrial wastewater from the food industry. The efficiency of the technology was evaluated with sodium hypochlorite addition to removing the adherent bacteria on the surface area of hollow fibers. The results showed that the bioreactor under the conditions of the second phase was excellent in removing Turbidity, TSS, COD, and $\mathrm{BOD}_{5}$ with a removal efficiency $99.96 \%, 89.52 \%, 93.56 \%$, and $99.36 \%$ respectively, when added $82 \mathrm{ml}$ of $\mathrm{NaOCl}$ in the bioreactor tank, and was a good removing of TP, and Ortho$\mathrm{P}$ with removal efficiency $60.76 \%$ and $48.95 \%$ respectively. Otherwise, a negative effect of $\mathrm{NaOCl}$ on both of $\mathrm{NO}_{3}-\mathrm{N}$ and $\mathrm{NH}_{4}-\mathrm{N}$ was obtained in term of removal where the minimum removal efficiency was observed when adding $82 \mathrm{ml}$ of $\mathrm{NaOCl}$ under the conditions of the second phase.
\end{abstract}

Keywords: MBR, Food Industry, $\mathrm{NaOCl}$, Activated sludge.

\section{Introduction}

Most countries suffer from water shortage and poor quality due to population growth, climate variability, and human activity, which leads to a food gap and decreasing of water resources. The situation is worsening by the pollution of freshwater resources, due to the discharge of untreated industrial and municipal wastewater into freshwater sources, thus constituting the main source of water pollution [1]. Industrial wastewater varies in the flow and pollution strength. The industrial wastewaters contain suspended, colloidal and dissolved (mineral and organic) solids. The wastewater may contain inert, organic or toxic materials and possibly pathogenic bacteria. The wastes may be drained to the sewer system provided if not have a noxious effect on treatment efficiency on the sewer system. Full treatment is necessary when the waste is discharged directly into surface or groundwater [2]. The membrane bioreactor, MBR is one of the leading technologies currently used in countries around the world for water reuse. Because of advances in technology and declining costs, MBR technology application for water reuse has increased sharply over the past few years [3]. MBR systems have been used to treat wastewater as a potential technique, especially for industrial wastewater treatment. MBR is an alternative biological treatment method associated with the conventional activated sludge process with its smaller footprint, less sludge production, and ability to operate under the production of high-quality effluent, [4]. The basic parameters for industrial wastewater characteristics include chemical oxygen demand, COD, biochemical oxygen demand $\mathrm{BOD}_{5}$, suspended solids, $\mathrm{SS}$, ammonium nitrogen, $\mathrm{NH}_{4}-\mathrm{N}, \mathrm{pH}$, turbidity, and Dissolved Oxygen, DO. Food industry wastewater is considered industrial wastewater which contains residues that consume the oxygen in receiving streams. Oxygen demand and nitrogenous pollutants in wastewater are a potential threat to the aquatic environment and hence to public health. The oxygen demand and ammonium nitrogen $\mathrm{NH}_{4}-\mathrm{N}$ can result in dissolved oxygen DO consumption of the received water body [5]. The most important criteria used for food industry wastewater to determine the quality of water are chemical oxygen demand, COD, and biochemical oxygen demand, $\mathrm{BOD}_{5}$. These parameters are important to evaluate the efficiency of wastewater treatment. Hollow fiber ultrafiltration UF membranes are

\footnotetext{
*Corresponding author: anmar.engi@hotmail.com
} 
flexibility during water treatment and can be used in a number of configuration processes to meet advanced effluent treatment objectives. These membranes used for removal of particular and colloidal contaminants. Also, can be combined with biological or chemical treatment to dispose of dissolved pollutants. In this paper, the analytical results obtained during the experimental tests for wastewater treatment of the food industries in a meat processing plant in Romania will be presented using the activated sludge method with MBR system type ZW-10 producing from Zenon ${ }^{\circledR}$ (General Electric) Company.

\section{Materials and Methods}

Figure 1, shows the schematic diagram of a hollow fiber MBR system used in this study. The membrane module ZW-10 is a polyethylene hollow fiber manufactured by Zenon-General Electric with an OCP chemistry, with a pore size of $0.036 \mu \mathrm{m}$ and total active area is $0.93 \mathrm{~m}^{2}$. The pilot plant used during the experiments was made available by the company Zenon KFT Hungary. This pilot plant is located in the hydraulic laboratory of the Technical University of Civil Engineering in Bucharest UTCB, Romania. This membrane module is a unique outside-in hollow fiber module that operates under a low vacuum instead of high pressure [6]. The membrane is installed in 26 liters volume of bioreactor plastic tank with dimensions of $18 \times 18 \times 80 \mathrm{~cm}$. The aeration of the activated sludge was performed by fine air bubble diffusers.

A Verder gear pump located in the center of the MBR system was used to create a negative suction head at the membrane module to sustain the permeate stream flow rate. This pump permits for the reversal of the flow in the pump according to the power requirements, to ensure reverse supply role in the backwashing process of the membranes. The bioreactor was operated in two phases, (RI, RII), with different hydraulic retention times "HRT". Industrial wastewater provided by food industry factory of meat processing was used as a sample of wastewater in this study. The conventional aeration method for activated sludge was used by two phases. The first phase, RI was conducted in 09-Nov.-2017, while the second phase, RII, was conducted in 29-Nov.-2017. The HRTs were selected to be 2, 4, and 8 hours for RI, and 2, 4, 8, and 24 hours for RII respectively with the adding $6 \mathrm{ml}$ of $\mathrm{NaOCl}$ compound during backwashing process, also, $82 \mathrm{ml}$ of $\mathrm{NaOCl}$ at HRT 24 hours in RII was added in the bioreactor tank with mixed liquor.

The sludge activation process is the first step that was implemented before the operation of the bioreactor system to treat the wastewater samples. In the first phase, 550 liters of industrial wastewater sample was pumped into the storage tank with 20 liters of the mixed liquid of activated sludge at concentration $3.542 \mathrm{gr} / 1$. While 1000 liters of the raw wastewater taken from the same source was pumped into the storage tank with 40 liters of the mixed liquid of activated sludge at concentration 3.234 $\mathrm{gr} / \mathrm{l}$ to sludge activation purpose in the second phase as a pre-treatment process. $13 \mathrm{l} / \mathrm{h}$ of the air flow rate was pumped continuously by using 4 air dispensers during the aeration process of the experiment. The recycling pump was operated in the storage tank to ensure the mixing between the sludge and the wastewater sample and activate all aerobic bacteria.

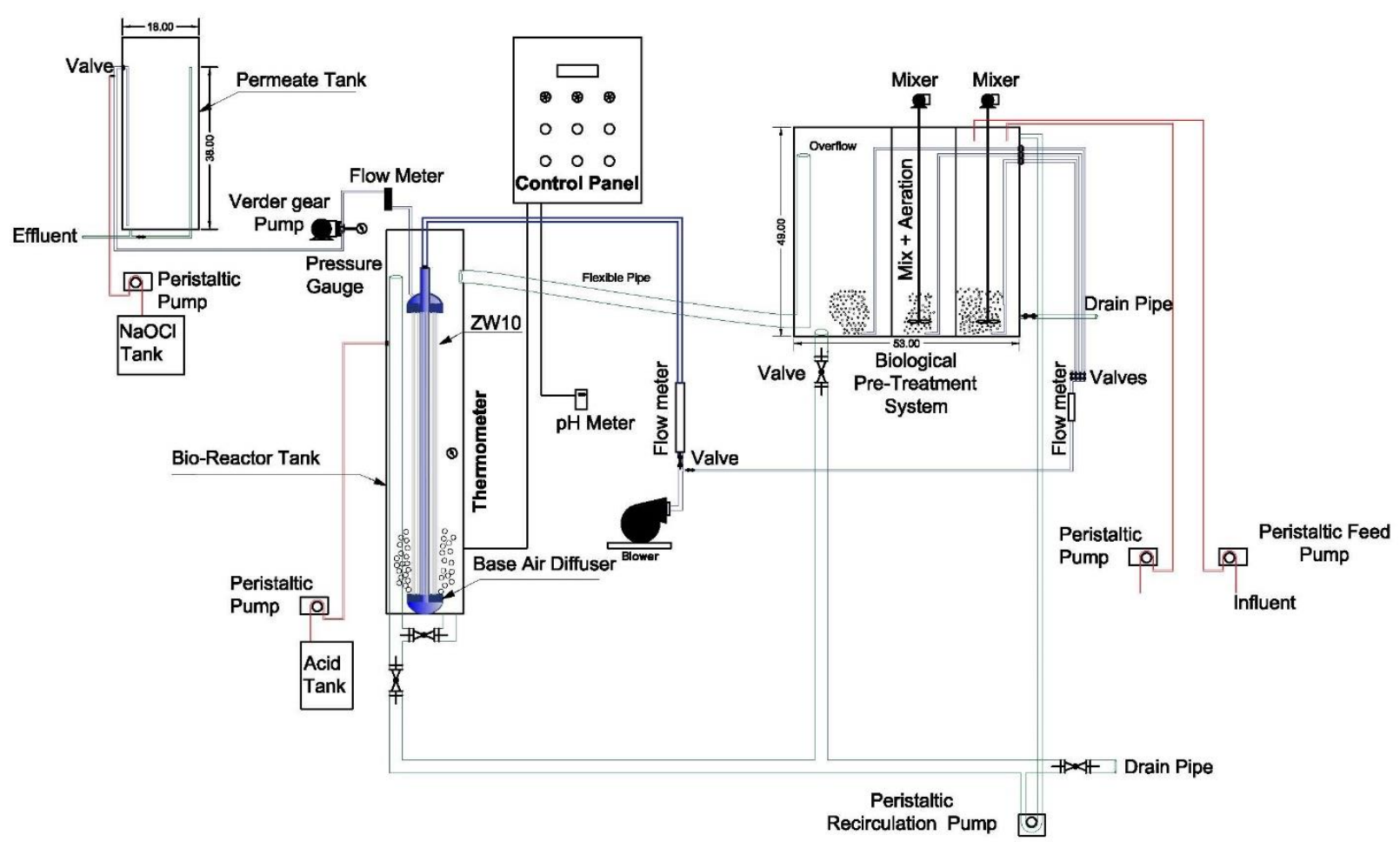

Fig. 1. Schematic diagram of pilot plant for MBR system used in this study. 
During the aeration process, the liquid mixture was pumped from the storage tank to the activated sludge tank of the pilot plant by using two peristaltic pumps with flow rate 32.31 and $28.31 \mathrm{l} / \mathrm{h}$, then to the bioreactor tank by overflow pipe fixed inside the activated sludge tank. The aeration process was carried out in the activated sludge tank using 3 diffusers at air flow rate $61 / \mathrm{min}$, whereas, the air in the bioreactor was pumped from the base of the membrane at flow rate $50 \mathrm{l} / \mathrm{min}$ to prevent the adhesion of sludge around the surface area of the membrane. Six milliliters of the sodium hypochlorite " $\mathrm{NaOCl}$ " was added during the backwashing process by used a peristaltic pump with flow rate $6 \mathrm{ml} / \mathrm{min}$ distributed by $3 \mathrm{ml}$ per 30 seconds, while $82 \mathrm{ml}$ of $\mathrm{NaOCl}$ was added by another peristaltic pump to the bioreactor tank with the mixed liquid at HRT 24 hours during RII at a flow rate of 4.1 $\mathrm{ml} / \mathrm{min}$. The treatment process and backwash process were programmed at time $600 \mathrm{sec}$, and $30 \mathrm{sec}$ respectively.

\section{Water Quality Parameters Sampling Tests}

and

During each run in the bioreactor system, a number of water quality parameters were tested to examine the influent and effluent physical, and biochemical properties.

These parameters are DO, $\mathrm{pH}$, Temperature, Turbidity, TSS, MLSS, $\mathrm{BOD}_{5}, \mathrm{COD}, \mathrm{NO}_{3}-\mathrm{N}, \mathrm{NH}_{4}-\mathrm{N}$, TP, and OP. Sixteen samples were collected to analyze physical and biochemical tests. The samples were taken from the storage tank, activated sludge tank, and effluent tank. Regarding the first phase "RI", seven samples were taken with 2, 4, and 8 hours of aeration time, the first sample was taken from the raw wastewater at reached to the laboratory in 09-Nov.-2017, at 9:45 am. While, nine samples were taken on the second phase" RII" with 2, 4, 8 , and 24 hours of aeration time and the first sample was taken from the raw wastewater at reached to the laboratory in 29-Nov.-2017, at 10:45 am. These times were selected in the treatment process to determine the BOD removal efficiency, COD removal efficiency, and suspended solids removal efficiency, as well as determine the effect of the chemical compound represented by $\mathrm{NaOCl}$ on the treatment efficiency. The $\mathrm{DO}, \mathrm{pH}$, and temperature were measured on-site before sampling.

\section{Results and Discussions}

The collected samples were tested for twelve of physical and biochemical tests. The biochemical tests were analyzed in the chemical laboratory of UTCB, which consists of mixed liquor suspended solids, MLSS, total suspended solids, TSS, biochemical oxygen demand, $\mathrm{BOD}_{5}$ chemical oxygen demand, COD, nitrate nitrogen, $\mathrm{NO}_{3}-\mathrm{N}$ ammonium nitrogen, $\mathrm{NH}_{4}-\mathrm{N}$, total phosphate, $\mathrm{TP}$, and orthophosphate, Ortho-P, whereas, the physical tests were carried out on the site which consists of dissolved oxygen $\mathrm{DO}, \mathrm{pH}$, and temperature.
The codes of influent and effluent samples were I1, E1, I2, and E2 during RI and RII runs respectively. Analysis of these results is presented in the following subsections.

\subsection{Temperature}

The temperature of the wastewater samples for RI varied between 19 and $20.5^{\circ} \mathrm{C}$ with gradual increasing during the operating time as shown in figure 2 . The maximum and minimum temperature of I1 was found, $20.3^{\circ} \mathrm{C}$ and $19.7^{\circ} \mathrm{C}$, respectively, whereas, the maximum and the minimum of $\mathrm{E} 1$ was found $20.5^{\circ} \mathrm{C}$ and $19.9^{\circ} \mathrm{C}$ respectively. Regarding RII, the temperature of the wastewater samples varied between 16.8 and $18.3^{\circ} \mathrm{C}$ with gradual increasing during the operating time except at time $24 \mathrm{~h}$, where it was decreased as shown in figure 3. The maximum and minimum temperature of $\mathrm{I} 2$ was found, $17.4^{\circ} \mathrm{C}$ and $17^{\circ} \mathrm{C}$, respectively, whereas, the maximum and the minimum of E2 was found $18.3^{\circ} \mathrm{C}$ and $17.5^{\circ} \mathrm{C}$ respectively. The temperature during RI was slightly higher than RII, this may have been due to the variation of weather conditions. The effluent temperatures were in general higher than the influent, due to the biochemical processes of microorganisms in the bioreactor.

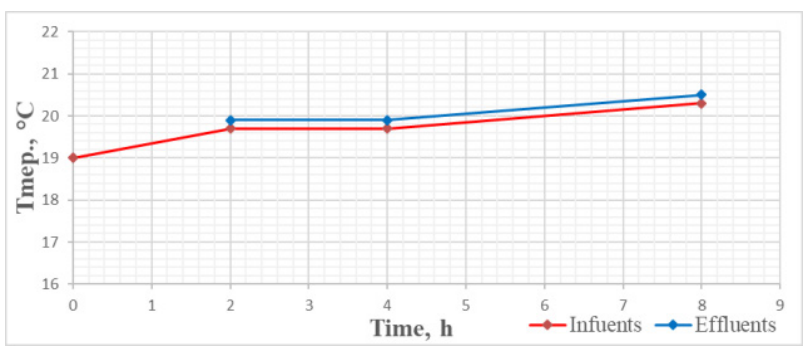

Fig. 2. Variations of the temperature in RI.

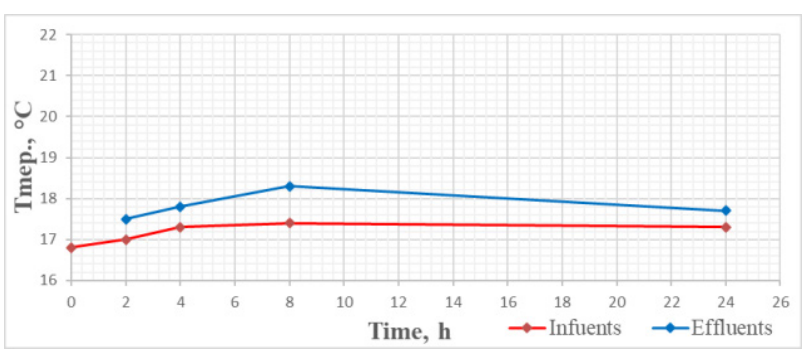

Fig. 3. Variations of the temperature in RII.

\subsection{Dissolved Oxygen, DO}

The dissolved oxygen concentrations of the wastewater samples during RI varied between 0.04 and $4.98 \mathrm{mg} / \mathrm{l}$ as shown in figure 4.

The maximum and minimum DO of I1 was 1.48 and $0.45 \mathrm{mg} / 1 \mathrm{respectively,} \mathrm{whereas,} \mathrm{the} \mathrm{maximum} \mathrm{and}$ minimum of E1 were found 4.98 and $2.14 \mathrm{mg} / \mathrm{l}$ respectively. All DO concentrations in influents during RII run were found to be close to zero. Generally, the DO concentrations during RII run varied between 0.09 and 8.4 $\mathrm{mg} / \mathrm{l}$ with low concentrations in the influents, as shown in 
figure 5. The maximum and minimum of E2 were found 8.4 and $5.64 \mathrm{mg} / \mathrm{l}$ respectively.

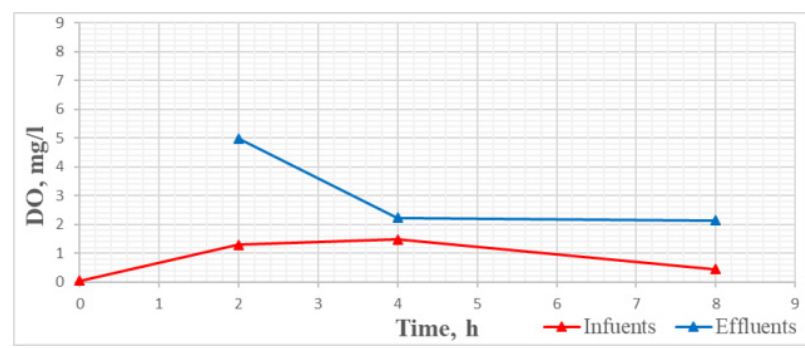

Fig. 4. Variations of the DO in the RI.

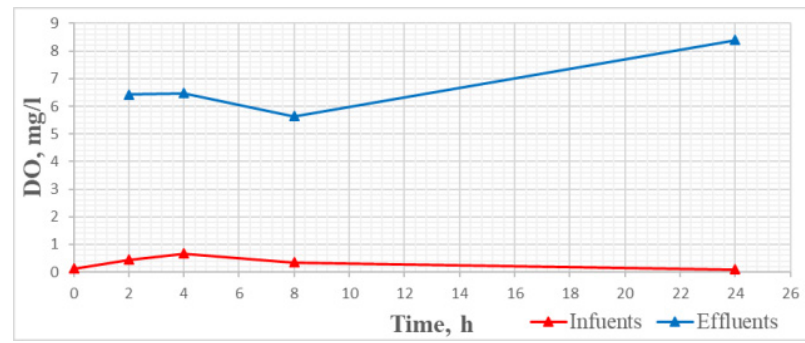

Fig. 5. Variations of the DO in the RII.

The low value of DO at 12 may refer to the Oxygen depletion in the pretreatment process represented (during sludge activation) by the microorganisms for growth and organic biodegradation comparing with short to long HRTs.

\section{3. $\mathrm{pH}$}

The variation values of $\mathrm{pH}$ during $\mathrm{RI}$ and $\mathrm{RII}$ runs are shown in figures 6 and 7 respectively. All the influent values of $\mathrm{pH}$ were higher than 7 except the raw wastewater, where was less than 7.

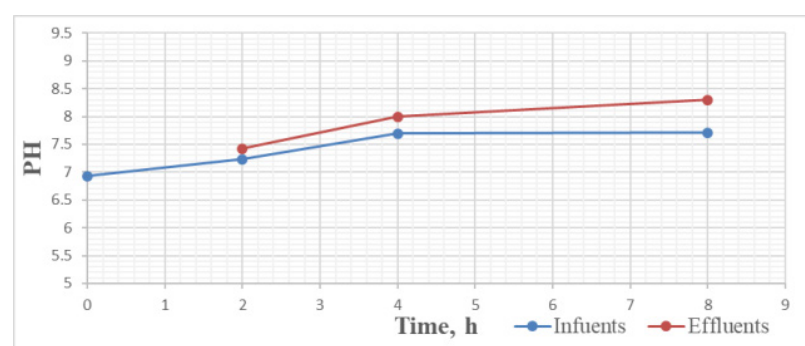

Fig. 6. Variations of the $\mathrm{pH}$ in the RI.

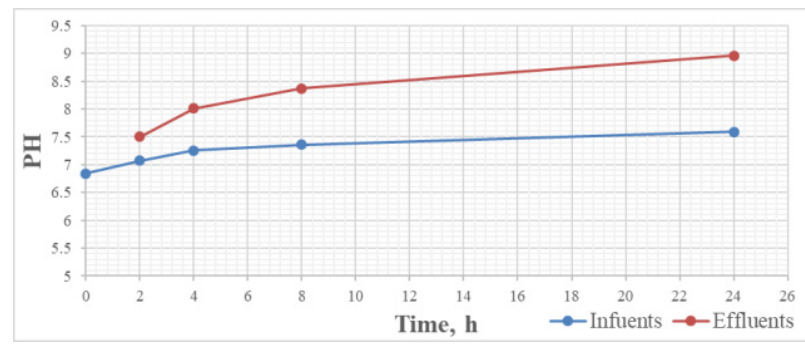

Fig. 7. Variations of the $\mathrm{pH}$ in the RII.

The average, maximum, and minimum $\mathrm{pH}$ value of I1 was $7.54,7.71$, and 7.23 , respectively, while the average, maximum, and minimum $\mathrm{pH}$ value of $\mathrm{I} 2$ was $7.32,7.59$, and 7.07, respectively. The $\mathrm{pH}$ values of the effluents during the tests RI and RII were higher than that of the influents, because of $\mathrm{NaOCl}$ effect in the bioreactor and indicate an alkaline solution. The average $\mathrm{pH}$ values of E1 and E2 were found 7.91 and 8.21 respectively.

\subsection{Turbidity}

The tested values of the turbidity during RI runs are shown in figure 8 . The turbidity concentration of raw wastewater was 205 NTU and, the average, maximum, and minimum value of I1 was 271, 305, and 217 NTU respectively, whereas the average, maximum, and minimum value of E1 was 1.11, 1.51, and $0.37 \mathrm{NTU}$ respectively.

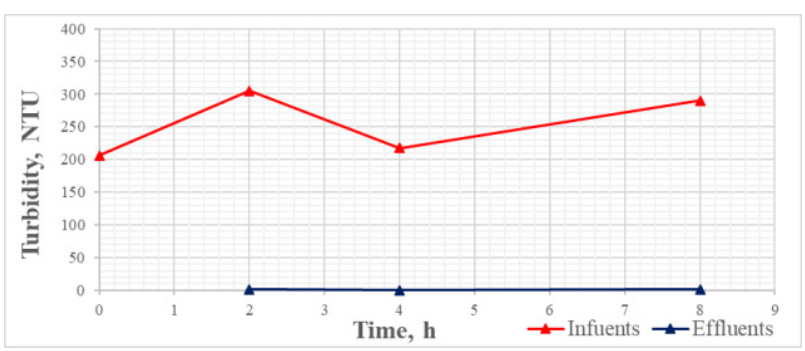

Fig. 8. Variations of the turbidity in the RI.

Figure 9 shows the values tested of turbidity concentration during RII runs. The turbidity value of raw wastewater was 250 NTU and the average, maximum, and minimum value of I2 was 310, 346, and 292 NTU respectively, whereas the average, maximum, and minimum value of E2 was 2.28, 4.35, and 0.1 NTU respectively. The membrane filter showed an excellent turbidity removal, where the removal of turbidity during all tests carried out varied between $99.27 \%$ and $99.82 \%$ for RI runs and $99.02 \%$ and $99.96 \%$ for RII runs. In general, all the turbidity of effluents during RI and RII runs were much less than that of the influents, this indicates that the membrane filter was very efficient in retaining solids.

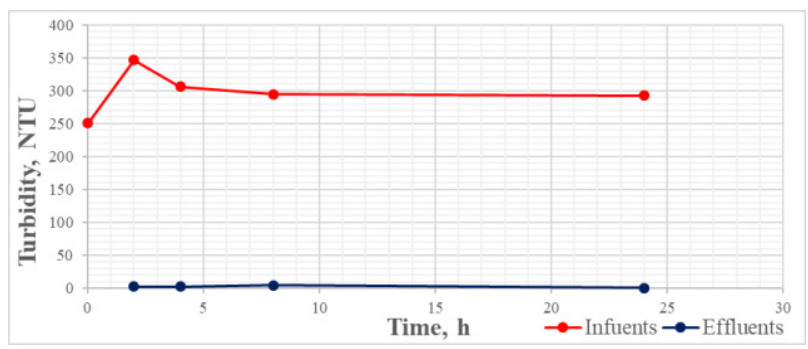

Fig. 9. Variations of the turbidity in the RII.

\subsection{Total Suspended Solids, TSS}

The results of tested values for total suspended solids during the RI and RII runs was shown in figures 10 and 11. The results obtained from these tests are the raw wastewater and effluents. On the first test, the TSS value of raw wastewater sample was $522 \mathrm{mg} / \mathrm{l}$, and the average, maximum, and minimum value during E1 runs was 121, 132 , and $112 \mathrm{mg} / \mathrm{l}$ respectively. The removal of TSS during all tests performed in RI runs varied between 
$74.71 \%$ and $78.54 \%$. The results of tested values for TSS during the RII runs are shown in figure 11 . The TSS value of raw wastewater sample was $744 \mathrm{mg} / \mathrm{l}$, and the average, maximum, and minimum value during E2 runs was 164, 242 , and $78 \mathrm{mg} / \mathrm{l}$ respectively. The removal of TSS during all of RII runs varied between $67.47 \%$ and $89.52 \%$.

Total suspended solids are greatly related to the turbidity. Generally, the results obtained showed, the highest removal efficiency of TSS achieved when adding of $\mathrm{NaOCl}$ amount, where it reached $89.52 \%$.

\subsection{Mixed Liquor Suspended Solids}

The results of mixed liquor suspended solids "MLSS" tested that were taken from influents during the RI and RII runs were shown in figures 10 and 11 . The average, maximum, and minimum value of MLSS during the I1 was 586, 672, and $452 \mathrm{mg} / 1$ respectively, whereas, the average, maximum, and minimum value during the I 2 was 932, 1046, $868 \mathrm{mg} / \mathrm{l}$ respectively. The results obtained are shown that decreased of MLSS concentrations with the time during aeration process, that means the decline of the number of microorganisms represented by sludge due to the consumption of organic matter in the wastewater.

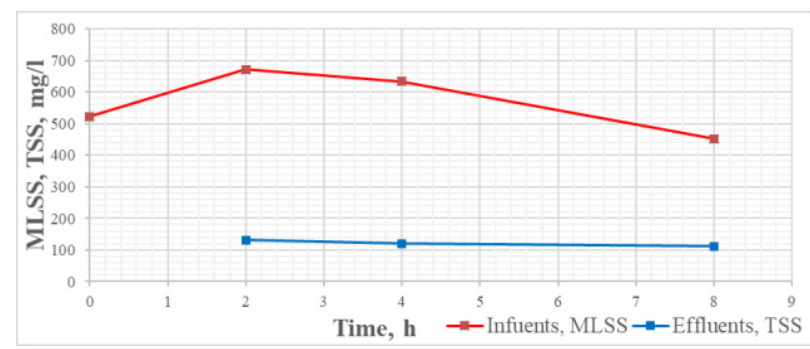

Fig.10. Variations of the MLSS and TSS in RI run.

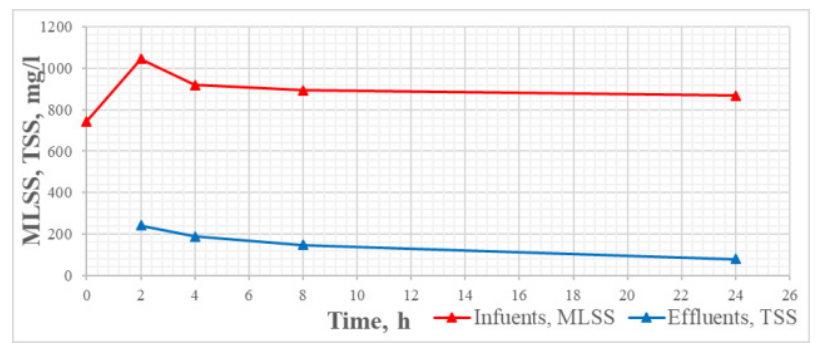

Fig.11. Variations of the MLSS and TSS in RII run.

\subsection{Biochemical Oxygen Demand, $\mathrm{BOD}_{5}$}

The tested values of $\mathrm{BOD}_{5}$ during $\mathrm{RI}$ and RII runs are shown in figures 12 and 13, respectively. The tested values of $\mathrm{BOD}_{5}$ of both influents, $\mathrm{I} 1$ and $\mathrm{I} 2$, depended on the incoming organic load in the sample of raw wastewater, where in the RI was found $1442 \mathrm{mg} / \mathrm{l}$, and in the RII was $1864 \mathrm{mg} / \mathrm{l}$. The $\mathrm{BOD}_{5}$ values of influents fluctuated between 1398 and $946 \mathrm{mg} / \mathrm{l}$ during RI runs, and between 1808 and $1483 \mathrm{mg} / \mathrm{l}$ during RII runs respectively. Also, the $\mathrm{BOD}_{5}$ values of the effluent during RI runs decreased gradually and reached to $340 \mathrm{mg} / \mathrm{l}$. Whereas for RII runs, the $\mathrm{BOD}_{5}$ of the effluents has been significantly decreased and reached to $12 \mathrm{mg} / \mathrm{l}$ after 24 hours of aeration due to the effect of $\mathrm{NaOCl}$ compound. The removal efficiency of $\mathrm{BOD}_{5}$ during the RI runs varied between $70.87 \%$ to $76.42 \%$, whereas, the removal efficiency during RII runs varied between $69.96 \%$ to $99.36 \%$ respectively. The fourth test during RII showed the highest removal efficiency, due to the addition $82 \mathrm{ml}$ of $\mathrm{NaOCl}$ into the bioreactor tank with the mixed liquor during bioreactor process. The difference in removal between RI and RII runs due to the temperature, organic load, and $\mathrm{NaOCl}$ addition. The temperature represents an effective factor in the solute extraction because it has a strong influence on the bioreactor reaction rate, [7].

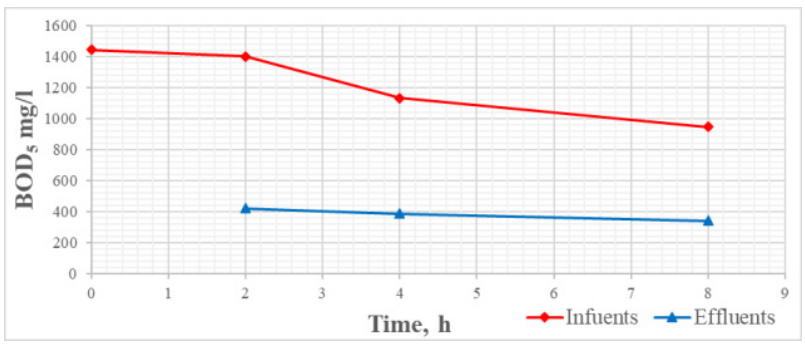

Fig. 12. Variations of the $\mathrm{BOD}_{5}$ in RI run.

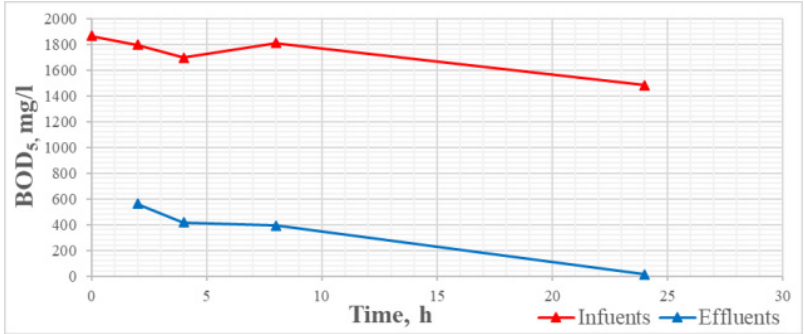

Fig. 13. Variations of the $\mathrm{BOD}_{5}$ in RII run.

\subsection{Chemical Oxygen Demand, COD}

The tested values of the COD during RI and RII runs are shown in figures 14 and 15 respectively. The COD tested values of both raw wastewater samples in RI and RII runs were found 2458 and $2534 \mathrm{mg} / \mathrm{l}$ respectively. The average, maximum, and minimum COD concentration of I1 were 1830,2227 , and $1421 \mathrm{mg} / 1$ respectively, whereas, the average, maximum, and minimum COD concentration of I 2 were 2256, 2458, and $2112 \mathrm{mg} / 1$, respectively.

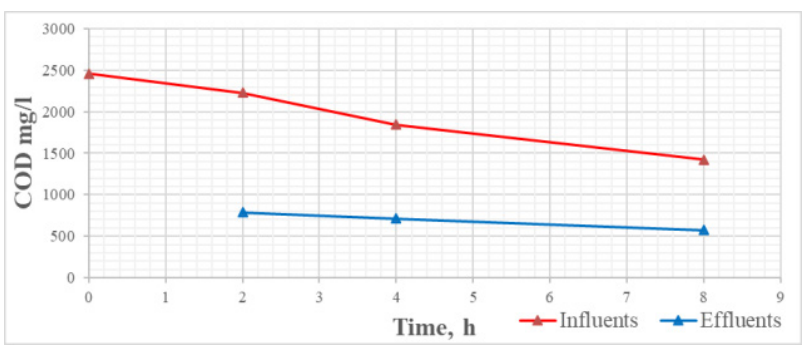

Fig. 14. Variations of the COD in the RI run.

Regarding effluents test, the values of COD during RI runs was decrease gradually to reached $576 \mathrm{mg} / \mathrm{l}$ with the average concentration $691 \mathrm{mg} / \mathrm{l}$, whereas, the COD of the effluent E2 during RII runs has been significantly decreased to reached $163 \mathrm{mg} / \mathrm{l}$ at HRT 24 hours due to the effect of $\mathrm{NaOCl}$, with the average concentration $598 \mathrm{mg} / \mathrm{l}$. Most of removed COD was due to BOD removal and most 
of the remained part is for the biologically was degradable of organic matter. The removal efficiency of COD during RI runs varied between $67.97 \%$ and $76.56 \%$, while the removal efficiency during RII runs varied between $65.53 \%$ and $93.56 \%$, respectively.

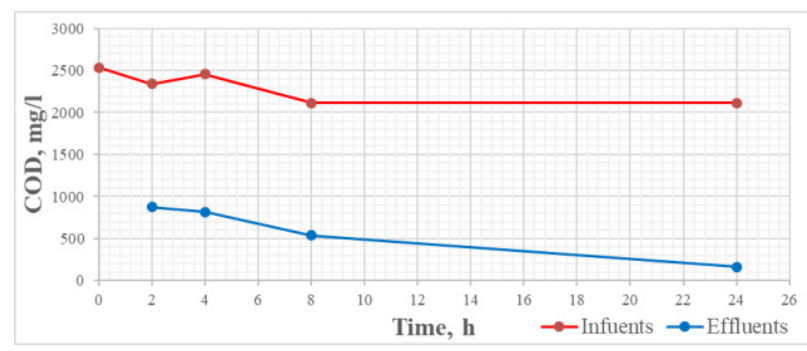

Fig. 15. Variations of the COD in RII run.

The results show a reduction in COD values when 82 $\mathrm{ml}$ of $\mathrm{NaOCl}$ was added in the fourth test during RII runs, thus achieving the highest removal efficiency.

\subsection{Nitrate Nitrogen $\mathrm{NO}_{3}-\mathrm{N}$}

The tested values of the $\mathrm{NO}_{3}-\mathrm{N}$ during $\mathrm{RI}$ and $\mathrm{RII}$ runs are shown in figures 16 and 17, respectively. In these tests, the $\mathrm{NO}_{3}-\mathrm{N}$ values of both raw wastewater in RI and RII runs were found 3.87 and $3.92 \mathrm{mg} / 1$ respectively.

Regarding influents, the average, maximum, and minimum of $\mathrm{NO}_{3}-\mathrm{N}$ concentration during $\mathrm{RI}$ runs was $2.76,2.89$, and $2.53 \mathrm{mg} / \mathrm{l}$, respectively, while the average, maximum, and minimum of $\mathrm{NO}_{3}-\mathrm{N}$ concentration during RII runs were $3.35,3.73$, and $3.14 \mathrm{mg} / 1$, respectively. For effluents, the average, maximum, and minimum concentration during RI runs was $2.47,2.62$, and $2.2 \mathrm{mg} / \mathrm{l}$ respectively, and the average, maximum, and minimum concentration during RII runs was $2.74,3.11$, and 2.36 $\mathrm{mg} / \mathrm{l}$ respectively.

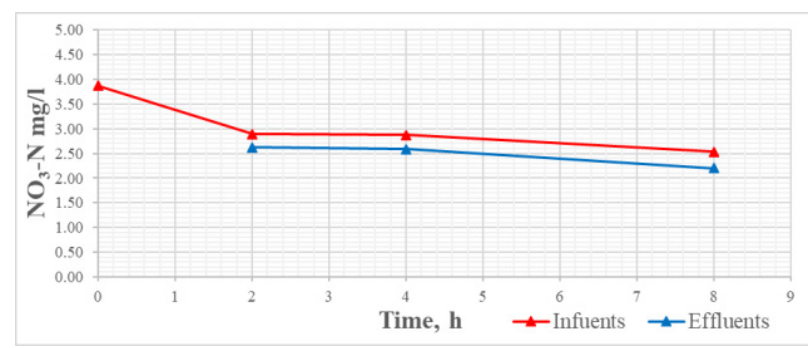

Fig. 16. Variations of the $\mathrm{NO}_{3}-\mathrm{N}$ in $\mathrm{RI}$ run.

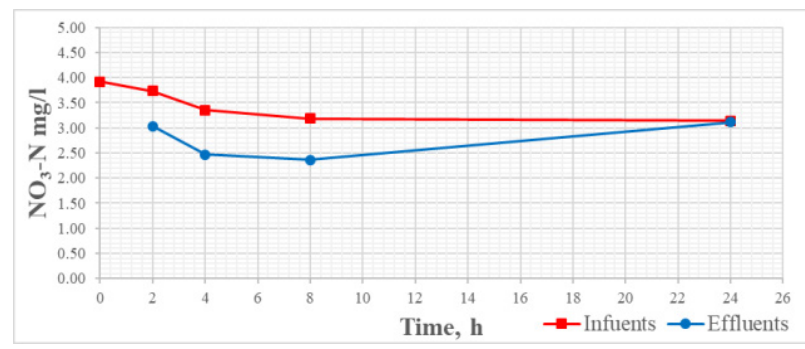

Fig. 17. Variations of the $\mathrm{NO}_{3}-\mathrm{N}$ in RII run.

In these tests, there was no significant effect on the $\mathrm{NO}_{3}-\mathrm{N}$ removal efficiency of effluents, as well as, the negative effect of sodium hypochlorite $\mathrm{NaOCl}$ on the effluents in terms of removal was observed, where the values of the nitrate concentrations in effluents were very close to the influent thus achieving a minimum removal efficiency. Generally, the removal efficiency of $\mathrm{NO}_{3}-\mathrm{N}$ during the RI runs varied between $32.3 \%$ and $43.15 \%$, while, the removal efficiency during RII runs varied between $20.66 \%$ and $39.8 \%$, respectively.

\subsection{Ammonium Nitrogen $\mathrm{NH}_{4}-\mathrm{N}$}

The tested values of the $\mathrm{NH}_{4}-\mathrm{N}$ during $\mathrm{RI}$ and $\mathrm{RII}$ runs are shown in figures 18 and 19 , respectively. The $\mathrm{NH}_{4}-\mathrm{N}$ values of raw wastewater samples for both phases were found 19.5 and $16.5 \mathrm{mg} / \mathrm{l}$, respectively. During RI runs, the $\mathrm{NH}_{4}-\mathrm{N}$ removal within the effluents varied between $41.01 \%$ and $67.33 \%$, while, in RII runs, sodium hypochlorite $\mathrm{NaOCl}$ had a negative effect in term of removal, where the negative removal efficiency was obtained when $82 \mathrm{ml}$ of $\mathrm{NaOCl}$ added with the mixed liquor in the bioreactor tank, where reached to $(-39.4 \%)$, otherwise, the removal efficiency during RII runs varied between $35.27 \%$ and $78.42 \%$. The average, maximum, and minimum value of influent I1 during RI runs were $15.16,16.5$, and $13.42 \mathrm{mg} / \mathrm{l}$ respectively, whereas, the average, maximum, and minimum value of effluent E1 were $8.44,11.5$, and $6.37 \mathrm{mg} / \mathrm{l}$, respectively. While, the average, maximum, and minimum value of influent I2 during RII runs were 11.98, 12.5, and $11.62 \mathrm{mg} / 1$ respectively, whereas, the average, maximum, and minimum value of effluent E2 were 11.56, 23, and 3.56 $\mathrm{mg} / \mathrm{l}$, respectively.

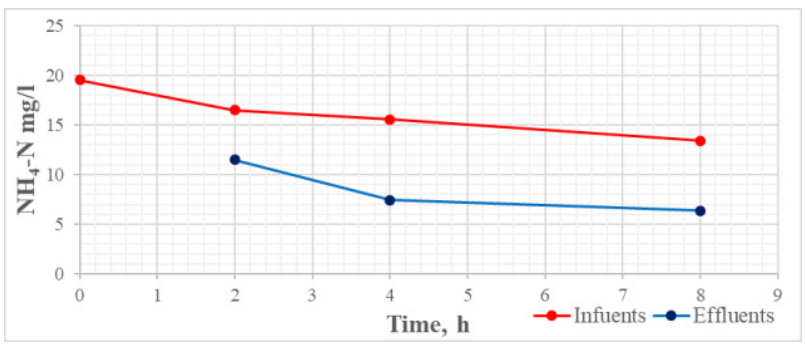

Fig. 18. Variations of the $\mathrm{NH}_{4}-\mathrm{N}$ in $\mathrm{RI}$ run.

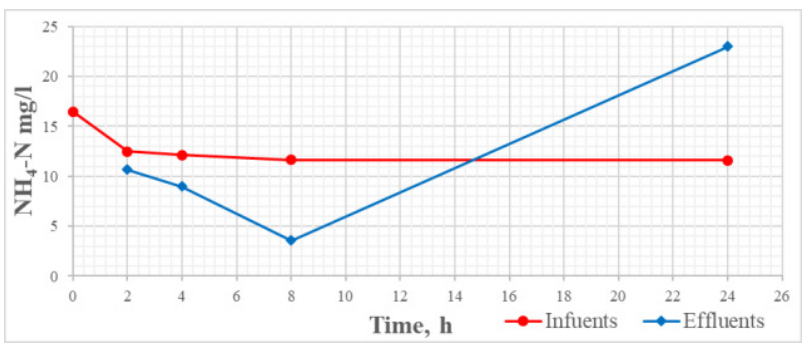

Fig. 19. Variations of the $\mathrm{NH}_{4}-\mathrm{N}$ in RII run.

\subsection{Total Phosphate $\mathrm{PO}_{4}-\mathrm{P}$}

The variations of TP concentration during RI runs are shown in figure 20, while, the variations of TP concentration during RII runs are shown in figure 21 . The concentration of TP of raw wastewater samples in RI and RII was $55 \mathrm{mg} / \mathrm{l}$ and $57.6 \mathrm{mg} / \mathrm{l}$ respectively, and the 
concentration of TP for I1 during RI runs fluctuated between 54.4 and $60.4 \mathrm{mg} / \mathrm{l}$, while, for I2 during RII runs fluctuated between 57.2 and $67 \mathrm{mg} / 1$ with gradual increase in both of RI and RII runs. For bioreactor process, the concentration of TP for E1 runs fluctuated between 34.4 and $40.2 \mathrm{mg} / \mathrm{l}$, while, for E2 runs fluctuated between 22.6 and $50 \mathrm{mg} / \mathrm{l}$, with the gradual decrease has been observed in both of RI and RII runs after 4 hours of aeration time. The removal efficiency of E2 higher than that in E1. The highest TP removal was obtained because of the $\mathrm{NaOCl}$ effect, where it has the effect on the decreasing of total phosphate concentration and obtaining the highest removal efficiency, where reached $61 \%$. In general, the removal efficiency of TP during RI and RII runs varied between (26.91\%-37.45\%) and (13\%-61\%), respectively. The low removal efficiency of TP refers to the system works aerobically.

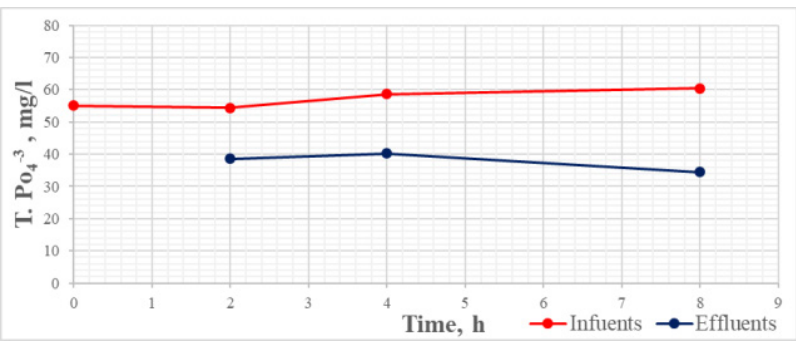

Fig. 20. Variations of the TP in RI run.

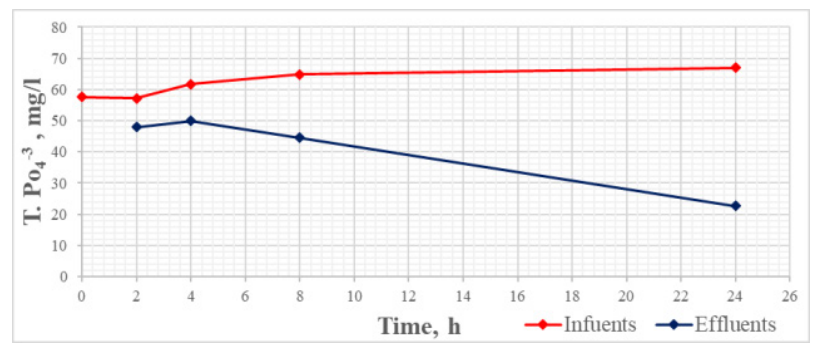

Fig. 21. Variations of the TPin RII run.

\subsection{Orthophosphate $\mathrm{PO}_{4}-\mathrm{P}$}

The orthophosphate, Orth-P is the form of phosphate that can be used and consume by the microorganisms. The organic phosphate can be converted to orthophosphate after decomposition. The tested values of the orthophosphate during RI and RII runs are shown in figures 22 and 23, respectively. The concentration of Orth-P of raw wastewater samples in RI and RII was 38.2 $\mathrm{mg} / \mathrm{l}$ and $38 \mathrm{mg} / \mathrm{l}$ respectively, and the concentration of Orth-P in I1 during RI runs fluctuated between 38.4 and $47.2 \mathrm{mg} / \mathrm{l}$, while the concentration of Orth-P in I2 during RII runs fluctuated between 38.8 and $46.4 \mathrm{mg} / \mathrm{l}$ depending on the concentrations of Orth-P within the influent. The difference between the influent of Orth-P and TP represents the polyphosphate. The effluents generally have lower Orth-P concentration values than that of the influents and follow the same trend of fluctuation as in the TP. The removal efficiency of E2 was higher than that of E1. Also, the highest removal of Orth-P recorded was in the RII runs due to the $\mathrm{NaOCl}$ effect, where this compound had an effect on decreasing the orthophosphate concentrations and thus obtaining the highest removal efficiency, where reached $49 \%$. In general, the removal efficiency of Orth-P during RI and RII runs varied between (4.19\%-14.14\%) and (13\%-49\%), respectively. The low removal efficiency of Orth-P refers that the system works aerobically.

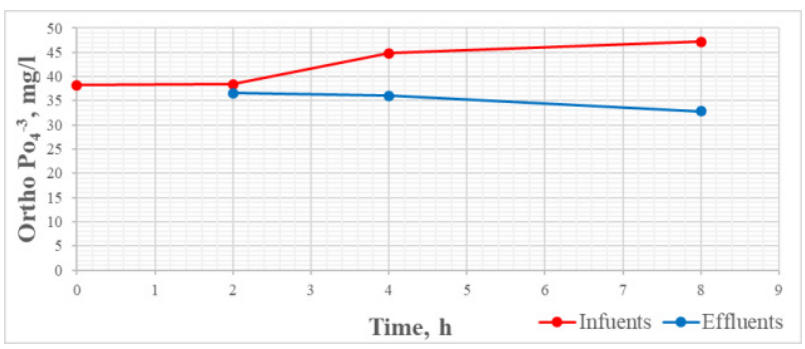

Fig. 22. Variations of the OP in RI run.

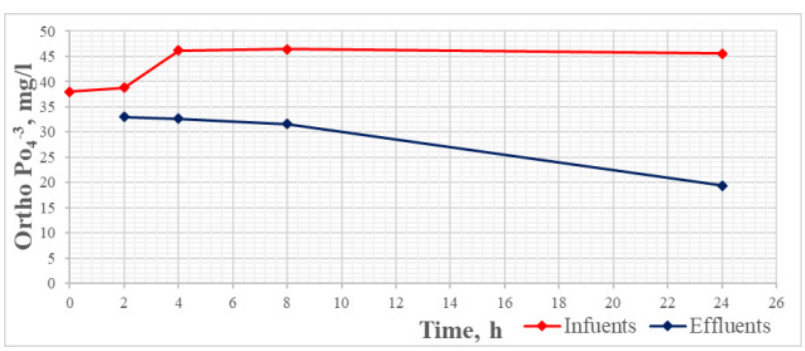

Fig. 23. Variations of the OPin RII run.

\section{Conclusions:}

The two phases of experimental trials using MBR system were carried out with HRTs of 2-8 $\mathrm{h}$ and 2-24 h showed that the bioreactor can be used efficiently to treat industrial wastewater. The wastewater was treated by using ZW10 hollow fibers membrane. On the first phase "RI", sodium hypochlorite "NaOCl" has been added during the backwashing process as a sterilizer in water as well as to prevent clogging in the pores of the membranes. On the second phase "RII", $\mathrm{NaOCl}$ has been added during the backwashing process at HRT 2-24 h, but, at $24 \mathrm{~h}$ of aeration, $82 \mathrm{ml}$ of $\mathrm{NaOCl}$ was added with mixed liquor in the bioreactor tank to study its effect on the treatment process. The results obtained can be summarized as follows:

1. The $\mathrm{pH}$ value had gradually increased with HRT during the aeration process for both phases, where the $\mathrm{pH}$ value during RI increased from 6.9. to 7.71, while during RII, the $\mathrm{pH}$ value increased from 6.84 to 7.59 . The reason for this increase is the disintegration and oxidation of the organic matter during the aeration process, which leads to the formation of $\mathrm{CO}_{2}$. Some part of the $\mathrm{CO}_{2}$ released as a gas from the aeration tank, that resulting in a decreasing of acidity in the water thus increasing the $\mathrm{pH}$ value. Generally, the $\mathrm{pH}$ value for the effluents was higher than that of influents, due to the effect of the $\mathrm{NaOCl}$ on the treatment process, which indicates that it is an alkaline solution. 
2. For the treatment process, the membrane filter showed an excellent turbidity removal for both phases, thus indicates that the membranes filter was very efficient in retaining solids. the highest removal efficiency observed when adding $82 \mathrm{ml}$ of $\mathrm{NaOCl}$ in the bioreactor tank in RII runs.

3. For TSS, BOD and COD removal during the treatment process, a very good removal has obtained for COD, $\mathrm{BOD}_{5}$ and TSS concentrations during RI runs where ranged between (67.97\%-76.56\%) and (70.87\%$76.42 \%)$ and (74.71\%-78.54\%) respectively, while the effect of $\mathrm{NaOCl}$ compound on effluent during RII was observed., whereas, the best results were obtained after 24 hours of aeration when added $82 \mathrm{ml}$ of $\mathrm{NaOCl}$ to the bioreactor tank with mixed liquor, where the treatment process was excellent in removing of COD, $\mathrm{BOD}_{5}$, and TSS with removal efficiency $93.56 \%$, $99.36 \%$, and $89.52 \%$ respectively.

4. The addition of the $\mathrm{NaOCl}$ compound during the RII runs had a negative effect on the nitrogen removal represented by nitrates and ammonium, where the minimum removal efficiency of $\mathrm{NO}_{3}-\mathrm{N}$ was observed when adding $82 \mathrm{ml}$ of $\mathrm{NaOCl}$ in the fourth run where it was $20.66 \%$, whereas, a negative removal efficiency of ammonium was observed when adding $82 \mathrm{ml}$ of $\mathrm{NaOCl}$ in the fourth run where it was $(-39.39 \%)$. Generally, the variation of removal efficiency for the $\mathrm{NO}_{3}-\mathrm{N}$ except for the fourth run in RII ranged between $(32.3 \%-43.15 \%)$ in RI and (22.7\%-39.8\%) in RII, whereas, the variation of removal efficiency for the $\mathrm{NH}_{4}-\mathrm{N}$ except for the fourth run in RII ranged between (41.03\%-67.33\%) in RI and (35.27\% -78.42\%) in RII.

5. The addition of the $\mathrm{NaOCl}$ compound during the RII runs had a positive effect on the phosphor removal represented by total phosphate and ortho-phosphate, where the highest removal efficiency of total phosphate and ortho-phosphate was observed when adding $82 \mathrm{ml}$ of $\mathrm{NaOCl}$ in the fourth run where it was $60.76 \%$ and $48.95 \%$ respectively. In general, the variation of removal efficiency for the TP except for the fourth run in RII ranged between (29.82\%$37.45 \%)$ in RI and (16.67\%-22.57\%) in RII, whereas, the variation of removal efficiency for the Ortho-P except for the fourth run in RII ranged between (4.19\%-14.14\%) in RI and (13.16\%- 16.84\%) in RII.

\section{References}

1. Miriam Sartor, Martin Kaschek, Valko Mavrov, Feasibility study for evaluating the client application of membrane bioreactor (MBR) technology for decentralised municipal wastewater treatment in Vietnam, Desalination., $224 \quad$ (1-3), $172-177 \quad$ (2008) https://www.sciencedirect.com/science/article/p ii/S0011916408000477.

2. Mohamed Nazih Abdallh, Walid Sayed Abdelhalim, Hisham Sayed Abdelhalim, Industrial Wastewater Treatment of Food
Industry Using Best Techniques, IJESI, 5 (8), $15-$ 28

http://ijesi.org/papers/Vol(5)8/version2/C0508021528.pdf.

3. Naghizadeh, A., Mahvi, A. H., Vaezi, F., and Naddafi, K., Evaluation of hollow fiber membrane bioreactor efficiency for municipal wastewater treatment, Sci. and Eng., (IAEH), 5 (4), 257-268 http://www.bioline.org.br/request?se08042.

4. Xinhu Wang, Victor W.C. Chang, and Chuyang Y.Tang, Osmotic membrane bioreactor (OMBR) technology for wastewater treatment and reclamation: Advances, challenges, and prospects for the future, J. M. Sci., 504, 113-132 (2016)

https://doi.org/10.1016/j.memsci.2016.01.010.

5. Metcalf and Eddy Inc., Wastewater Engineering: Treatment, Disposal and Reuse 3rd ed., New York, McGraw-Hill, (1991) https://trove.nla.gov.au/work/17704228.

6. Water Environment Research Foundation, Membrane Bioreactors: Feasibility and Use in Water Reclamation, Project 98-CTS-5, http://www.werf.org.

7. V. S. Kislik, Liquid Membranes: Principles and Applications in Chemical Separations and Wastewater Treatment, Amsterdam, the Netherlands Linacre House, Jordan Hill, Oxford OX2 8DP, UK: Elsevier (2010) https://www.researchgate.net/publication/26668 7952_Liquid_Membranes_Principles_and_Appl ications_in_Chemical_Separations_and_Waste water_Treatment. 